\title{
Penerapan Teknologi Informasi Untuk Pemberdayaan Tim Penggerak Pkk Desa Waru Rembang
}

\author{
Fajar Sodiq1, A.Aviv Mahmudi ${ }^{2}$ \\ 1,2Sekolah Tinggi Ilmu Ekonomi YPPI Rembang \\ e-mail: 1fajaryppi@gmail.com, 2viva.altaf@gmail.com
}

\begin{abstract}
Abstrak
Peranan Usaha Mikro Kecil dan Menengah (UMKM) sangatlah penting, UMKM berkontribusi penuh sebagai wadah untuk dapat menumbuhkan perekonomian desa dan produk local. Tim penggerak PKK Desa Waru merupakan badan usaha yang dijadikan sebuah pusat pemberdayaan UMKM didesa waru yang memiliki beragam masalah salah satunya dalam kondisi pandemi seperti saat ini promosi warga sangat terbatasi. Keadaan tersebut memaksa warga Desa Waru untuk menghentikan promosi yang sebelum pandemi dilakukan secara langsung tatap muka. Tujuan dari kegiatan Pengabdian Masyarakat ini adalah untuk mengedukasi warga Desa Waru akan pentingnya pemasaran dengan memanfaatkan teknologi melalui media online serta implementasi teknologi informasi dan digital marketing. Metode pelaksanaan pengabdian pada masyarakat ini adalah pelatihan dalam penerapan teknologi informasi, pelatihan manajemen usaha dan manajemen keuangan, serta pendampingan program pelatihan. Hasil dari pelatihan yang kami berikan untuk mengatasi masalah UMKM Mitra adalah dengan memprioritaskan aspek pemasaran dengan melakukan pendampingan/pelatihan untuk mengimplementasikan teknologi informasi khususnya pemasaran online dan Digital Marketing berupa akun dari tokopedia, youtube, facebook bisnis dan instagram bisnis. Pada aspek manajemen memberikan pemahaman tentang pembukuan dan manajemen keuangan digital.
\end{abstract}

Kata kunci: UMKM desa waru, Digital Marketing, Manajemen Usaha, Teknologi Informasi, Pemasaran online.

\begin{abstract}
The role of Micro, Small and Medium Enterprises (MSMEs) is very important, MSMEs contribute fully as a forum to be able to grow the village economy and local products. The Waru Village PKK driving team is a business entity that is used as a center for empowering MSMEs in Waru Village which has various problems, one of which is in a pandemic condition as currently the promotion of residents is very limited. This situation forced the residents of Waru Village to stop promotions which were carried out face-to-face before the pandemic. The purpose of this Community Service activity is to educate the residents of Waru Village about the importance of marketing by utilizing technology through online media as well as the implementation of information technology and digital marketing. The method of implementing this community service is training in the application of information technology, business management training and financial management, as well as training program assistance. The results of the training we provide to overcome the problems of MSME Partners is to prioritize
\end{abstract}


the marketing aspect by providing assistance/training to implement information technology, especially online marketing and Digital Marketing in the form of accounts from Tokopedia, YouTube, Business Facebook and Business Instagram. In the management aspect, it provides an understanding of digital bookkeeping and financial management.

Keywords: Waru village SMEs, Digital Marketing, Business Management, Information Technology, Online marketing.

\section{Pendahuluan}

Desa Waru merupakan salah satu desa yang masuk pada wilayah Kecamatan Rembang, Kabupaten Rembang. Wilayah administratif Desa Waru terdiri dari 5 (lima) RW dan 33 RT, yang terbagi menjadi 5 (lima) wilayah pedukuhan yakni Waru Lor, Waru Tengah, Waru Kidul, Sono dan Playon. Sebagian besar masyarakat Desa Waru adalah petani, wiraswasta, karyawan swasta dan mengurus rumah tangga. Seperti halnya beberapa wilayah di Kabupaten Rembang yang memiliki potensi masyarakatnya, Desa Waru juga banyak yang memiliki potensi yang bisa dikembangkan, antara lain bidang pertanian dan industri rumah tangga, di bidang sosial memiliki PKK (Pembinaan Kesejahteraan Keluarga). PKK merupakan organisasi sosial yang dapat menunjang peningkatan kualitas sumber daya manusia dalam masyarakat luas, hingga ke pelosok pedesaan di bumi nusantara (Ningsih dkk, 2020).

PKK ini merupakan suatu program yang memiliki tujuan memberdayakan keluarga untuk meningkatkan kesejahteraan dengan sasarannya adalah keluarga dan perempuan, karena perbaikan posisi dari kondisi perempuan yang masih diharapkan mampu memperbaiki atau membantu masalah-masalah yang ada baik dalam segi pendidikan, kesehatan atau perekonomian. Sehingga keberdayaan perempuan di bidang ekonomi adalah salah satu indikator meningkatnya kesejahteraan (hanis dan marzaman, 2020). PKK Desa Waru merupakan salah satu wadah organisasi perempuan/ibu-ibu PKK. Perkumpulan Ibu-Ibu PKK yang aktif dalam kegiatan sosial warga, perkumpulan ini di pimpin Ibu Sukatmi (istri dari Kepala Desa Waru). Keterlibatan para ibu dalam kegiatan PKK ini didasarkan pada keinginan untuk berorganisasi, bersilaturahmi, berbagi informasi, dll. yang tujuannya untuk dapat mensejahterakan keluarga. Latar belakang pendidikan ibu-ibu PKK di Desa Waru beragam tetapi rata-rata hanya lulusan SMP dan SMA, dan sebagian besar adalah ibu rumah tangga dengan keadaan ekonomi keluarga yang berada pada ekonomi menengah ke bawah. Walaupun demikian, diyakini kaum ibu-ibu tersebut memiliki banyak kemampuan dalam meningkatkan kesejahteraan keluarga salah satunya melalui kegiatan PKK yang diikuti (Nurhayati, 2018).

PKK Desa Waru Rembang telah merancang banyak kegiatan sosial untuk warga, terlepas dari banyaknya kegiatan yang dirancang, terkadang pengurus PKK masih kebingungan dengan bagaimana merancang program yang pas yang dapat membuat warga masyarakat khususnya menyejahterakan keluarganya dengan meningkatkan kualitas hidup keluarga, misalkan dengan meningkatkan perekonomian keluarganya. 
Usaha Mikro, Kecil, Menengah (UMKM) merupakan salah satu cara untuk membangun perekonomian nasional, dimana perekonomian nasional diawali dengan membangun perekonomian di tingkat keluarga (UU No. 20 Tahun 2008 Tentang UMKM). Para pelaku UMKM dibawah koordinasi PKK Desa Waru terdiri dari berbagai usaha kreatif pembuatan cindera mata, produk-produk makanan, dan berbagai usaha jasa yang cukup berpotensi untuk berkembang, namun pertumbuhan ekonomi seakan stuck atau stagnan pada hasil yang sama tanpa peningkatan yang signifikan. Hal ini disebabkan tidak ada pemahaman mendalam bagaimana cara mengorganisasikan Usaha Kecil dan Menengah (UMKM) dengan baik, sehingga penghasilan yang didapat pun kurang maksimal. Di antara berbagai faktor penyebabnya, rendahnya tingkat penguasaan teknologi dan kemampuan wirausaha di kalangan UMKM menjadi issue yang mengemuka saat ini (Erlangga dkk, 2021)

Permasalahan Tim Pengerak PKK dalam mengelola UKM anggotanya disamping dana usaha adalah kurangnya penyuluhan atau pelatihan yang dilakukan secara berkelanjutan sehingga dapat memberi bekal dalam menghadapi persaingan dimasa yang akan datang, disamping itu memberi pengetahuan berwirausaha yang dengan menerapkan teknologi informasi untuk pengembangan pemasaran dan cara mengelola keuangan yang baik. Apalagi ditambah dengan merebaknya kasus virus covid-19 ini mempengaruhi kehidupan masyarakat khususnya dari segi kesehatan, pendidikan dan ekonomi. Pembatasan sosial sebagai upaya pemerintah dalam memutus rantai penyebaran covid-19 memiliki dampak yang besar di masyarakat diantaranya penurunan pendapatan masyarakat dan penurunan tingkat produksi (Ainiyah, 2021). Dengan adanya program pengabdian kepada masyarakat bagi tim penggerak Pembinaan Kesejahteraan Keluarga (PKK) di Lingkungan Desa Waru Rembang diharapkan dapat membantu Ibu-Ibu PKK untuk mengembangkan usahanya sehingga dapat meningkatkan kualitas hidup. Secara umum tujuan dari kegiatan pengabdian masyarakat ini adalah untuk mengembangkan dan meningkatkan kemampuan pemanfaatan teknologi informasi dan pembukuan sederhana pada UMKM yang dikelola ibu-ibu PKK di lingkungan Desa waru Rembang (Ramadani, 2020).

Pemanfaatan teknologi informasi dengan penggunaan media digital telah banyak membantu setiap orang dalam melakukan rutinitas. Beberapa media digital yang sering digunakan saat ini, yaitu: Facebook, Twitter, Instagram, dan YouTube. Fungsi dari penggunaan media digital meliputi: branding, sharing, promosi, maupun marketing (Wiranto, 2015). Perkembangan teknologi informasi dan internet juga berpengaruh besar terhadap perkembangan dibidang promosi produk. Hal tersebut tentunya sangat menguntungkan bagi promosi produk UMKM yang mengakibatkan peningkatan efektivitas jika dibandingkan dengan media konvensional. Aspek utama yang mempengaruhi peningkatan efektivitas promosi produk melalui internet adalah media yang interaktif, bersifat fleksibel dan responsif. Dengan memanfaatkan teknologi informasi, maka dapat memberikan potensi yang besar dalam meningkatkan pendapatan masyarakat dimasa pandemi covid-19 ini, dalam hal ini 
anggota Pembinaan Kesejahteraan Keluarga (PKK) Desa waru Rembang (Hadi dan Ardhi, 2020).
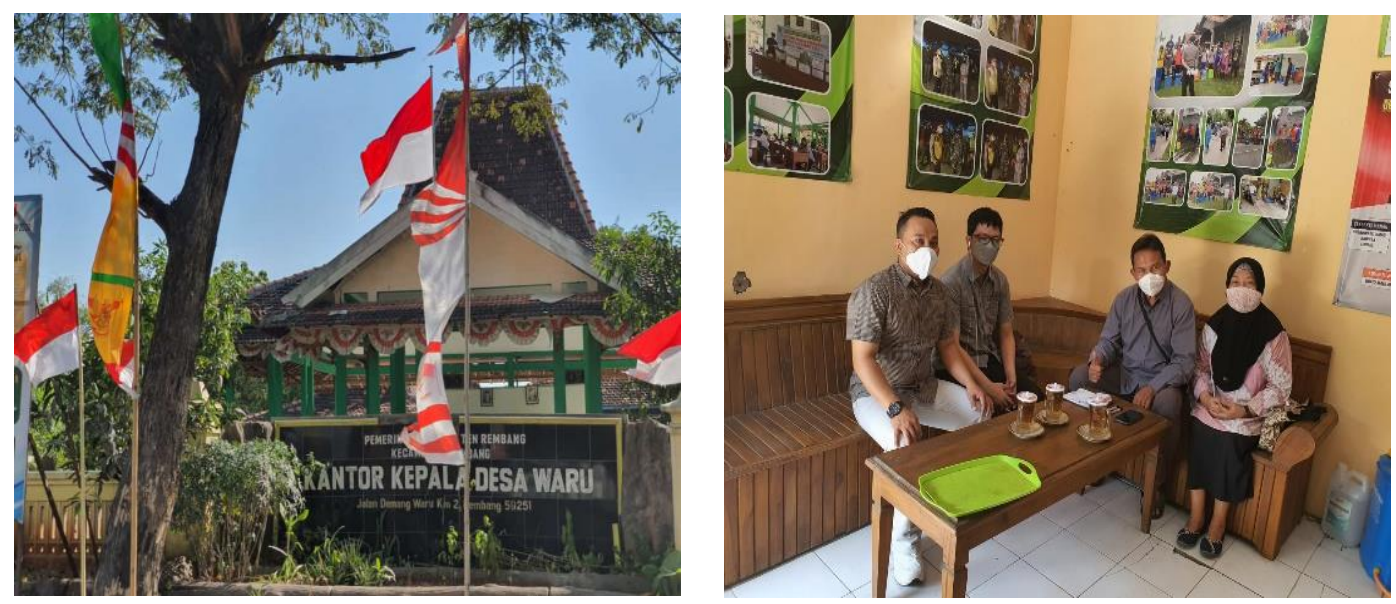

Gambar 1 Kantor Kepala Desa Waru dan Tim PKM Bersama Kepala Desa serta Ketua Tim PKK Desa Waru Rembang

Berdasarkan analisis situasi yang telah dipaparkan di atas dapat disimpulkan bahwa mitra pengabdian (Tim Penggerak PKK Desa Waru) memiliki beberapa permasalahan yang perlu diprioritaskan untuk dicarikan solusinya, yang menjadi prioritas adalah permasalahan adalah kurangnya pemanfaatan teknologi informasi untuk pemasaran produk dan jasa dan pengelolaan manajemen Keuangan. Berdasarkan identifikasi yang telah dilakukan, permasalahan prioritas mitra UMKM Tim Penggerak PKK Desa Waru yang telah disepakati yaitu:

1. Permasalahan Pemasaran

Pelaku UMKM masih melakukan pemasaran secara langsung pada konsumen, pelaku UMKM hanya mengandalkan promosi melalui media sosial dan belum mampu mengoptimalkan digital marketing.

2. Manajemen Usaha dan Administrasi Keuangan

Sistem manajemen dan administrasi keuangan masih dilakukan secara sederhana, belum terdapat pembagian tugas yang jelas.

Kegiatan pengabdian masyarakat ini bertujuan untuk memberikan pengetahuan dan pemahaman kepada mitra mengenai pentingnya teknologi informasi pemasaran online dan digital marketing bagi usaha mitra; mengajarkan praktik teknologi informasi pemasaran online dan digital marketing dengan memanfaatkan jejaring sosial kepada mitra/pelaku UMKM, serta memberikan pengetahuan dan peningkatan pemahaman manajemen usaha dan keuangan.

Program pengabdian masyarakat ini bermanfaat bagi beberapa pihak, antara lain:

1. Bagi Tim Pengabdian Pelaksana Program

Sebagai sarana dalam melaksanakan salah satu Tri Dharma Perguruan Tinggi yaitu pengabdian kepada masyarakat. 
2. Bagi Mitra/Masyarakat Sasaran Program

a. Peningkatan kemampuan dan keterampilan mitra dalam pemanfaatan teknologi informasi untuk menunjang pemasaran online.

b. Peningkatan kemampuan SDM dalam pengelolaan laporan keuangan

c. Pemberdayaan masyarakat untuk peningkatan produksi dan pengembangan UMKM.

\section{Metode}

Metode pelaksanaan pengabdian pada masyarakat ini adalah pelatihan dalam penerapan teknologi informasi, pelatihan manajemen usaha dan manjemen keuangan, serta pendampingan program (Rahmatika dkk, 2020). Tahap-Tahap Pengabdian Kepada Masyarakat:

1. Tahap Persiapan

Tahap persiapan merupakan tahap awal sebelum pelaksanaan kegiatan (Sujarwadi dkk, 2019). Dalam tahap ini ada beberapa hal yang dilakukan yaitu:

a. Pra Survei identifikasi permasalahan dan kebutuhan mitra.

b. Pembuatan Proposal: pembuatan proposal yang menawarkan solusi untuk permasalahan dan kebutuhan mitra.

c. Persiapan bahan pelatihan yaitu mempersiapkan bahan-bahan/peralatan yang akan dipakai untuk pelatihan.

2. Tahap Pelaksanaan Pelatihan

Pada tahap pelaksanan dilakukan pelatihan kepada ibu-ibu. Kegiatan dilaksanakan dibalai Desa Waru, Kecamatan Rembang, Kabupaten Rembang. Adapun pelatihan yang diberikan adalah penerapan teknologi informasi untuk pemasaran online, pelatihan manajemen usaha dan manjemen keuangan (Londa dkk, 2014).

3. Tahap Pendampingan

Pendampingan program dilakukan oleh tim pelaksana (Dosen dan Mahasiswa), pendamping dilakukan dengan tujuan untuk memastikan mitra dapat mengimplementasikan IPTEKS yang diberikan dalam program pengabdian kepada masyarakat.

4. Tahap Evaluasi Pelatihan

Evaluasi dilakukan dengan tanya jawab dan kuesioner untuk mengetahui tingkat pemahaman peserta pengabdian terhadap pelatihan yang diberikan.

5. Tahap Pembuatan Laporan

Pada tahap akhir dibuat laporan kegiatan Pengabdian Kepada Masyarakat tentang pemberdayaan ibu-ibu rumah tangga anggota PKK Desa Waru untuk meningkatkan ekonomi keluarga (Satwika, 2018).

Permasalahan yang telah disepakati oleh Tim Pengusul pengabdian masyarakat dan mitra untuk menjadi prioritas yang harus segera diselesaikan adalah: (1) 
Permasalahan pemasaran, (2) Permasalahan manajemen usaha dan administrasi keuangan (Istanti, 2020).

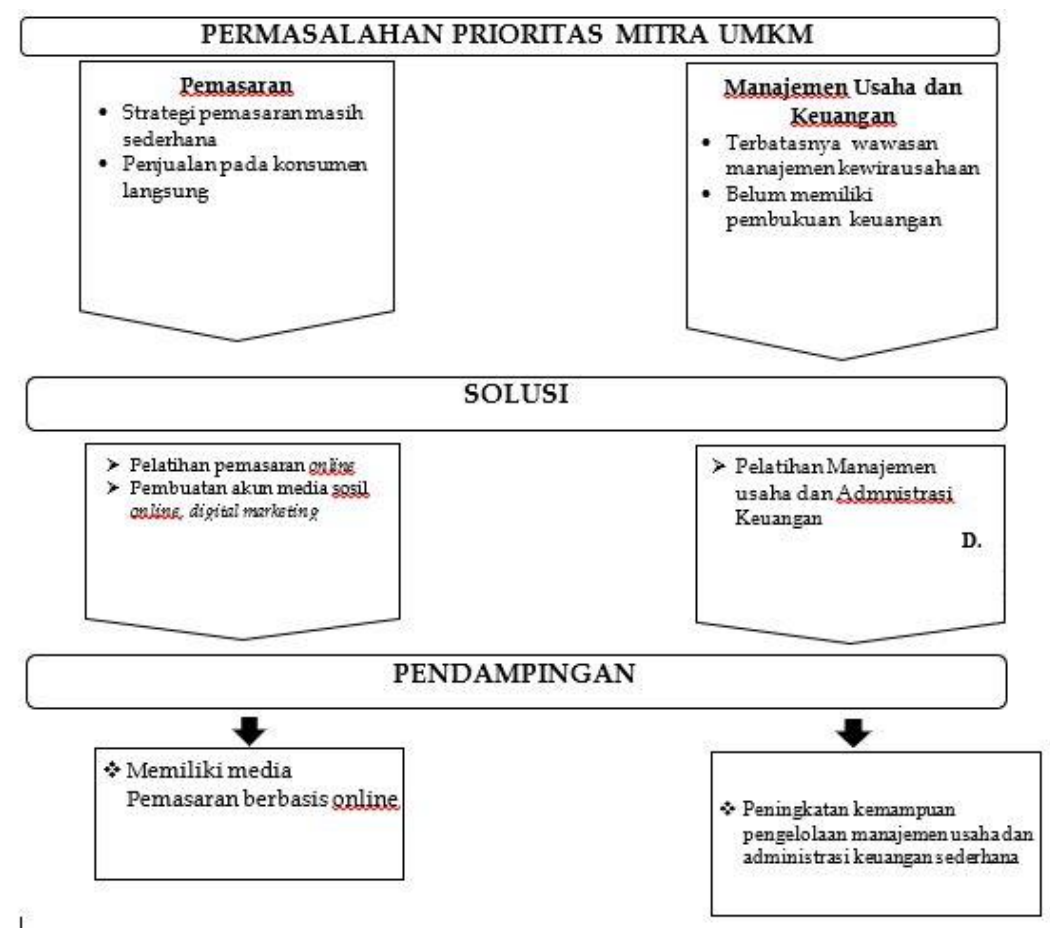

Gambar 2 Kerangka Pemecahan Masalah

Partisipasi mitra dalam program pengabdian masyarakat untuk Tim Penggerak PKK Desa Waru, Rembang antara lain adalah:

1. Dukungan dan kesanggupan kerjasama sebagai mitra dengan tim pengabdian masyarakat dari STIE YPPI Rembang yang telah disepakati.

2. Partisipasi mitra melalui pelaksanaan kegiatan secara bersama-sama dalam hal penyiapan sarana perangkat pendukung (handphone, laptop/modem, jaringan internet) yang dibutuhkan untuk proses penerapan pemasaran online.

3. Menentukan waktu kegiatan baik pelatihan maupun pendampingan usaha.

4. Mitra siap menyediakan tenaga dan tempat untuk pelaksanaan pelatihan.

5. Peserta yang mengikuti kegiatan pengabdian kepada masyarakat sebanyak 10 peserta dari berbagai UMKM dilingkungan desa waru rembang.

\section{Hasil Dan Pembahasan}

\section{Persiapan}

Pada tahap persiapan ini Tim PKM berkoordinasi dengan Kepala Desa Waru (Bapak Daryono) berhubungan dengan jadual pelaksanaan PKM. Jumlah peserta yang terdaftar sebanyak 15 UMKM akan tetapi dalam pelakasanaan pelatihan dan mengikuti kegiatan 10 UMKM binaan TP PKK Desa Waru Rembang. Seluruh peserta merupakan pemilik UMKM yang pada masa pandemi ini sangat terpengaruh dalam pemarannya. 


\section{Realisasi Pelaksanaan Kegiatan}

Sebelum pelaksanaan kegiatan dilaksanakan pada 11 September 2021 persiapan program aplikasi bisnis dan manajemen keuangan dilingkungan Balai Desa Waru Rembang, selanjutnya pelaksanaan kegiatan pada 15 September 2021 kegiatan praktikum yang dimulai dari pengenalan Teknologi Informasi dan Pemasaran Online dilanjutkan Terapan Teknologi Informasi di Era Marketplace kemudian pelatihan manajemen keuangan dan diakhiri digital marketing.

Kegiatan dilaksanakan dalam 1 hari dengan durasi pelatihan adalah \pm 5 jam, dengan rincian sebagai berikut

1. Pengenalan Teknologi Informasi dan Pemasaran Online \pm 60 menit.

2. Praktikum Penerapan Teknologi Informasi di Era Marketplace \pm 60 menit.

3. Praktikum manajemen keuangan bisnis digital \pm 60 menit.

4. Praktikum Digital Marketing \pm 60 menit.

5. Evaluasi keseluruhan materi \pm 45 menit

\section{Pelatihan}

Kegiatan tersebut diawali dengan pembukaan singkat oleh Kepala Desa Waru Rembang Bapak Daryono. Kegiatan praktikum dibagi menjadi 4 sesi Teknologi Informasi dan pemasaran online, penerapan teknologi informasi, manajemen keuangan dan digital marketing.

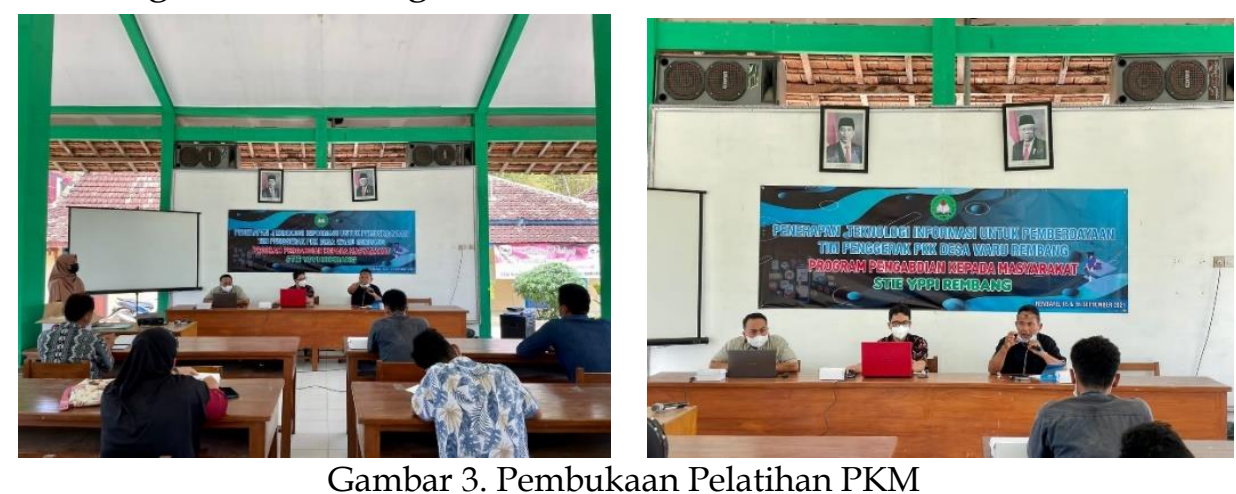

1. Pelatihan dan Praktikum Penerapan Teknologi Informasi

Pada praktikum ini pemateri memberikan arahan tentang pendaftaran email pada khususnya email Gmail yang mana akun tersebut dapat digunakan untuk pendaftaran diakun Marketplace. Pemateri dalam kegiatan adalah Fajar Sodiq, ST., M.Kom. (Ketua Tim PKM) kegiatan praktikum tersebut diawali dengan pemahaman fungsi email yang dapat dihubungkan dengan pendaftaran Marketplace. Pemateri juga menyampaikan dalam pembuatan email Gmail terhubung dengan no smartphone masing-masing. Sehingga bila terjadi lupa password maka Gmail akan memberikan kode otentikasi ke no selular yang telah didaftarkan. Dengan begitu pemilik akun tidak perlu khawatir apabila memiliki lebih dari email didalam smartphone nya. Dalam praktikum ini pemateri dibantu oleh 2 orang mahasiswa untuk mendampingi setiap peserta yang mengalami kesulitan atau kurang paham. 


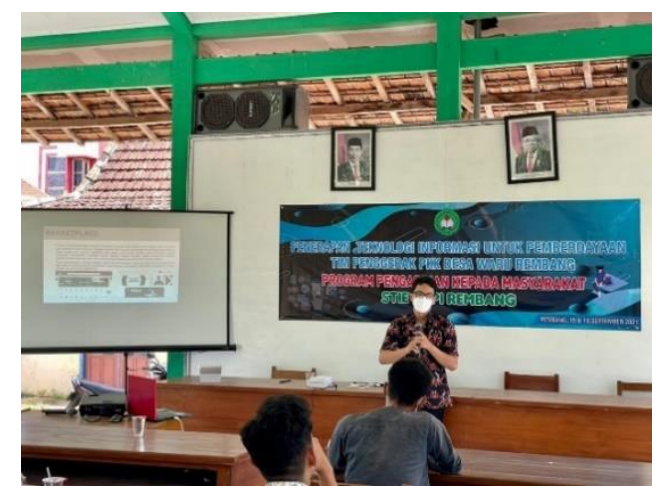

Gambar 4. Pemateri Menjelaskan Tentang Dasar Pembuatan Email

2. Pelatihan Optimalisasi Teknologi Informasi dan Pemasaran Online

Penyaji materi pemasaran online ini adalah tim pengabdian kepada masyarakat sendiri (A. Aviv Mahmudi, S.Kom., M.Kom.) sesuai dengan bidang dan keahlian pemateri. Pemateri menjelaskan pentingnya pemasaran dalam suatu bisnis dengan media online. Dengan memanfaatkan teknologi informasi dan komunikasi pemasaran suatu produk akan lebih luas jangkauannya, sehingga produk dapat dikenal masyarakat luas. Aplikasi Marketplace ada banyak diantaranya ada shopee, tokopedia, bukalapak, blibli dan sebagainya. Aplikasi-aplikasi tersebut tidak hanya menawarkan produk saja melainkan jasa juga dapat ditawarkan disana. Berbagai macam kemudahan yang diberikan media sosial dalam mempromosikan suatu barang maupun jasa membuat persaingan dagang di media sosial maupun Marketplacei menjadi sangat ketat. Sehingga pemilik UMKM dituntut untuk lebih kreatif dalam menarik calon pelanggannya.

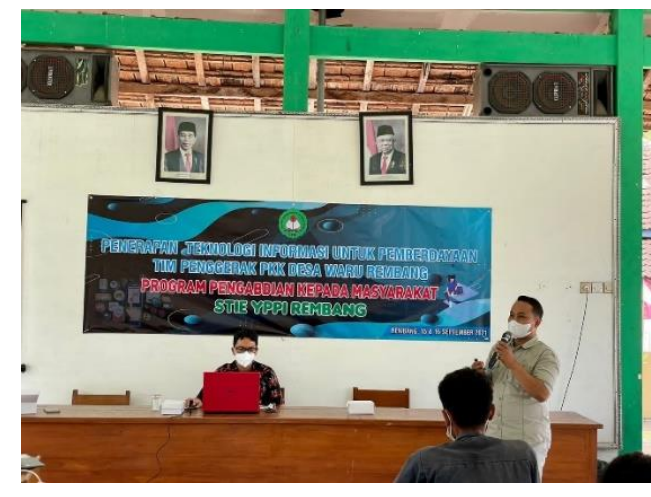

Gambar 5 Pemateri Menjelaskan Pentingnya Pemasaran Online

3. Pelatihan dan Praktikum Manajemen Keuangan

Dalam pelatihan manajemen keuangan ini peserta diminta untuk mengunduh aplikasi keuangan digital yang terdapat di play store smartphone masing-masing, dengan nama aplikasi Catatan Keuangan Harian. Pemateri mengajarkan. Penyaji materi ini diisi oleh dosen tamu (Dr. Riskin Hidayat, M.Sc.). Pemateri memberikan beberapa contoh input data keuangan besar modal yang digunakan untuk memulai usaha atau sebagai biaya untuk membeli bahan baku maupun peralatan. Selanjutnya input data pengeluaran dari pembelian peralatan hingga bahan baku 
hingga produk jadi dan siap untuk dipasarkan melalui media sosial (online) maupun secara langsung (offline).

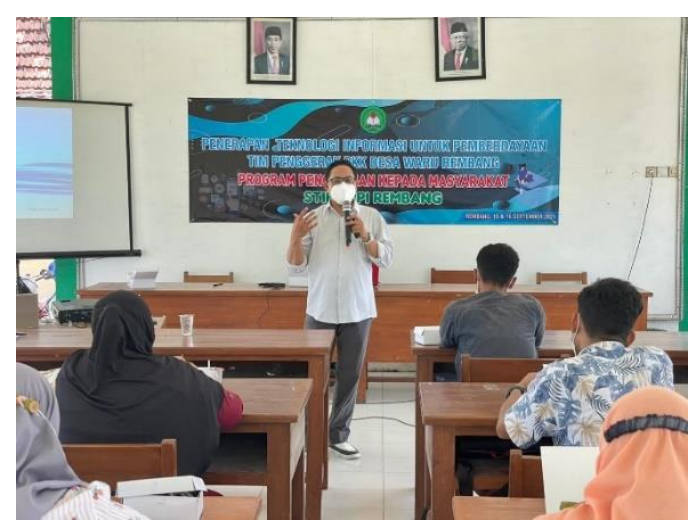

Gambar 6. Pemateri Menjelaskan Pentingnya Catatan Keuangan Harian Dalam Bisnis

4. Pelatihan dan Praktikum Digital Marketing

Pelatihan digital marketing ini merupakan pelatihan yang melibatkan 2 (dua) aplikasi antara lain facebook dan instagram. Penyaji dalam pelatihan ini diisi oleh dosen tamu (Ibu Wulan Suryandari, SE., MM.). Pemateri memberikan beberapa contoh pembuatan halaman pada facebook bisnis, dengan harapan dari pemateri dengan adanya halaman tersebut dapat menambah kepercayaan calon konsumen untuk membeli produk yang kita pasarkana atau jual. Berikutnya pemateri memberikan materi instagram bisnis, dalam instagram bisnis ini akun induk instagram dirubah sepenuhnya ke dalam instagram bisnis, sehingga pemilik akun setiap harinya akan mendapatkan grafik statis dari intagram bisnis berapa banyak akun yang telah mengaksesnya atau hanya melihat produk yang diunggah ke dalam akun intagram bisnis tersebut. Dengan begitu pemilik UMKM akan mengetahui dari area mana saja yang banyak mengakses akun instagram bisnis tersebut. Dengan begitu calon konsumen akan dengan mudah mendapatkan informasi berupa produk maupun harga produk yang dipasarkan.

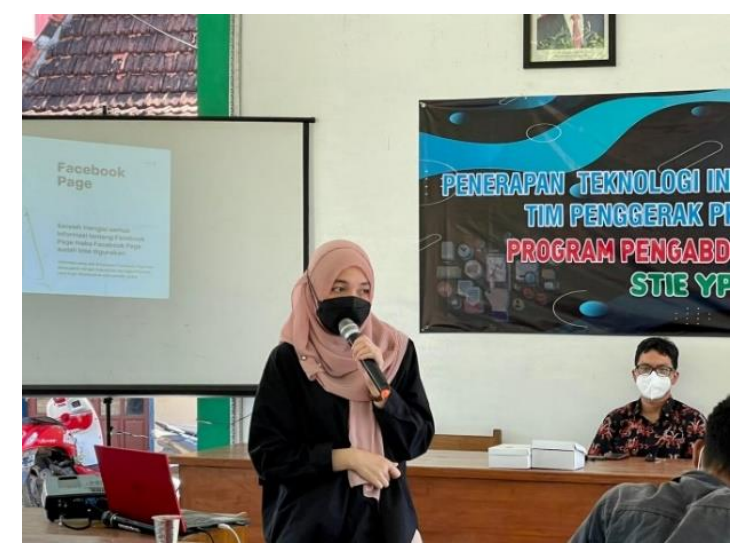

Gambar 7. Pemateri Menjelaskan Halaman Facebook 


\section{Evaluasi Hasil}

Tim memberikan pendampingan secara intens agar apa yang diberikan pemateri benar-benar dipahami oleh peserta pelatihan, dengan memberikan tugas, kemudian pemateri melihat hasil dari pelatihan tersebut untuk menilai bertambahnya pengalaman dalam bidang teknologi informasi yang selanjutnya dapat diimplementasikan dalam pemasaran produk masing-masing UMKM. Tingkat keberhasilan dari kegiatan pelatihan ini dilihat dari respon positif peserta dengan melakukan diskusi selama pemateri masih menyampaikan materinya. Melalui pelatihan ini peserta diharapkan mampu untuk mengembangkan pemasaran jasa maupun produknya lebih luas.

\section{Simpulan dan Rekomendasi}

Tim Penggerak PKK Desa Waru Rembang sebagai mitra atau sebagai penerima manfaat dari pelatihan kegiatan pengabdian kepada masyarakat. Dengan begitu umkm binaan tp pkk desa waru rembang memahami manfaat pemasaran di media sosial maupun marketplace, berbasis konten maupun photography yang dapat diunggah ke youtube, instagram, facebook bisnis maupun shopee, tokopedia dan sebagainya. Didalam marketplace peserta juga dapat menggunakan berbagai macam fitur yang ada, dapat juga memberikan diskon produk maupun diskon pengiriman. Materi yang disajikan terkait dengan pemanfaatan media sosial maupun marketplace sebagai sarana pemasaran. Berdasarkan hasil dari kegiatan pelaksanaan pengabdian kepada masyarakat dapat disimpulkan dalam beberapa hal sebagai berikut

Pelatihan ini disajikan beberapa materi terkait pemanfaat aplikasi untuk meningkatkan pemasaran peserta pelatihan (umkm) dengan memberikan pengetahuan manajemen keuangan harian, facebook dan instagram bisnis, juga berbagai macam marketplace.

Kemudahan materi yang disampaikan pemateri lebih mudah diterima, dicerna dan dipahami peserta dengan memberikan contoh secara visual.

Kegiatan berlangsung dengan lancar dan sesuai dengan harapan tim pelaksana pengabdian kepada masyarakat STIE YPPI Rembang.

Harapan tim program ini dapat dilanjutkan dan dikembangkan karena UMKM pada khususnya Binaan TP PKK Desa Waru rembang akan terus bertambah banyak sehingga dapat memperoleh manfaat dari pelatihan PKM (Apriani dkk, 2020).

Peserta diharapkan lebih pro aktif dalam meningkatkan pemahaman dan wawasan yang berhubungan dengan media sosial, marketplace, dan pemanfaatan keuangan digital.

\section{Daftar Pustaka}

Ainiyah, N. (2021). Pelatihan Identifikasi Biaya Usaha Dan Penentuan Harga Pokok Produksi Pakan Ikan Lele Desa Ngingasrembyong. Abdimas Nusantara: Jurnal Pengabdian Kepada

315-321. Http://Ejurnal.Unim.Ac.Id/Index.Php/Abdimasnusantara/Article/View/929 
Hanis, N. W., \& Marzaman, A. (2020). Peran Pemberdayaan Kesejahteraan Keluarga Dalam Pemberdayaan Perempuan Di Kecamatan Telaga. Publik (Jurnal Ilmu Administrasi), 8(2), 123. Https://Doi.Org/10.31314/Pjia.8.2.123-135.2019

Ningsih, D. R., Widyaningsih, S., \& Setyorini, D. (2020). Pemberdayaan Ibu-Ibu PKK Melalui Pelatihan Pembuatan Hand Gel Di Desa Purbayasa Padamara Purbalingga. Darma Sabha Cendekia, 2(2), 25-31. Http://Jos.Unsoed.Ac.Id/Index.Php/Dsc/Article/View/3720

Rahmat, D., Yang, T., \& Esa, M. (2008). Undang-Undang Republik Indonesia Nomor 20 Tahun 2008. 1.

Nurhayati, N. (2018). Peran Pemberdayaan Kesejahteraan Keluarga (Pkk) Dalam Upaya Peningkatan Kesetaraan Gender. Jurnal Trias Politika, 2(2), 153. Https://Doi.Org/10.33373/Jtp.V2i2.1465

Julian, E. S., Prawiroredjo, K., Tjahjadi, G., \& Erlangga, D. F. (2021). Pelatihan Aplikasi Marketplace Berbasis Mobile Untuk Kader Pkk Kecamatan Gambir. Versi Cetak), 4(2), 405-414.

Ramadani, D. M. (2020). Upaya Pemberdayaan Dan Kesejahteraan Keluarga (PKK) Dalam Pemberdayaan Perempuan Di Desa Mukti Jaya Kecamatan. E-Journal Ilmu Pemerintahan, 8(3), 677-690.

Rantung, J., Mandey, J., \& Londa, V. (2014). Peranan Pemberdayaan Kesejahteraan Keluarga (Pkk ) Dalam Menggerakkan Partisipasi Masyarakat Desa( Suatu Studi Di Desa Ongkau I Kabupaten Minahasa Selatan. Jurnal Administrasi Publik UNSRAT, 4(5), 1246.

Wiranto, S. (2015). Penerapan Teknologi Informasi Dan Komunikasi Sebagai Media Interaksi Guru-Siswa. Jurnal VARIDIKA, 26(2). Https://Doi.Org/10.23917/Varidika.V26i2.684

Hadi, A. S., \& Ardhi Khairi. (2020). Pemilihan Strategi Pemasaran Di Era Digital Pada Kelompok Ibu Pkk Desa Gadingharjo. Dinamisia: Jurnal Pengabdian Kepada Masyarakat, 4(1). Https:/ / Doi.Org/10.31849/Dinamisia.V4i1.3246

Enny Istanti, S. (2020). Pemberdayaan Masyarakat Di Desa Tanjungan Kec. Driyorejo Kab. Gresik Melalui Pemanfaatan Teknologi Informasi Dan Budidaya Toga. Jurnal BUDIMAS, 02(02), 82-88. $\quad$ Https://Jurnal.StieAas.Ac.Id/Index.Php/JAIM/Article/View/82-88/749

Sujarwadi, A., Musa, A., Afnan, A., Informasi, S., Yogyakarta, T., Internasional, H., Yogyakarta, U. T., \& Teknologi, U. (2019). Katering ( Jasa Boga ) Kelompok Pkk. Wikrama Parahita: Jurnal Pengabdian Masyarakat.

Wira Apriani, Nuraisana, \& Purba, E. (2020). Edukasi Dan Pelatihan Pemanfaatan Teknologi Informasi Untuk Ibu-Ibu Pkk Desa Jati Baru. BERNAS: Jurnal Pengabdian Kepada Masyarakat, 1(4), 465-469. Https://Doi.Org/10.31949/Jb.V1i4.469 
Angga Diputra, I. P. W., Raditya Putra, I. G. L. A., \& Satwika, I. P. (2018). Sistem Informasi Pkk Berbasis Website Dengan Fitur Mobile Di Kelurahan Penatih Kota Denpasar. Jurnal Teknologi Informasi MURA, 10(2), 92. Https://Doi.Org/10.32767/Jti.V10i2.389

Rahmatika, R., Dhika, H., \& Isnain, N. (2020). Penerapan E-Commerce Pada Kelompok PKK Di Kelurahan Pabuaran - Cibinong. Jurnal Pkm Pengabdian Kepada Masyarakat, 3(3), 218. Https://Doi.Org/10.30998/Jurnalpkm.V3i3.4614 